\title{
A study of prisoners: from Bentham's Panopticon to modern electronic surveillance. Problems and perspectives
}

\author{
Nicola Malizia \\ Associate Professor of Sociology of Law, Deviance and Social Change, Faculty of Sciences of Man and Society, University of Enna "Kore” - Italy. \\ DOI: 10.29322/IJSRP.12.01.2022.p12102 \\ http://dx.doi.org/10.29322/IJSRP.12.01.2022.p12102
}

\begin{abstract}
Although in the last decades of the twentieth century modern and evolutionary technology has allowed the introduction of new forms of prisoner surveillance, both in intra-mural and extra-mural terms, the study conducted, starting from the brilliant intuition of Jeremy Bentham's Panopticon and its functional prison engineering, The study, starting from the brilliant intuition of the Panopticon of Jeremy Bentham and its functional prison engineering, has investigated, in a comparative perspective, both the first methodologies of control of prisoners and the modern and technological processes of surveillance that appear, however, far from the general and disciplinary purposes of the past, fulfilling, today, only tasks of mere control of the person in a well-defined space. Electronic surveillance shares with the prison the effect that Foucault recognised in Bentham's Panopticon, that is, to induce in the prisoner a conscious state of visibility that ensures the functioning of power, making surveillance permanent in its effects, even if discontinuous in its action. No other substantive purpose is discernible. The application of the electronic bracelet, which represents the most evolved form of remote electronic surveillance in Italy, still raises doubts as to its effectiveness and often clashes with problems of material availability of such devices and with the limits of applicability, albeit technologically supported by GPS technology. If the imperative, today as in the past, is that of a containment or repression of the freedom of the prisoner locked up in a cell of a few square metres or inside the house with an electronic system of remote surveillance, the question remains whether such measures really contribute to the re-education and re-socialisation of the convicted person, or whether they are a timed instrument only to maintain social order.
\end{abstract}

Index Terms- prisoners, electronic surveillance, deviance, human freedom, technology and society.

\section{INTRODUCTION}

$I^{n}$ 1791, the philosopher Jeremy Bentham designed a circular building with a turret in the middle in order to optimise the surveillance of prisoners. In this structure, called a 'panoptic', the warden would therefore be able to monitor the prisoners without them being noticed. The idea came at a time when the costs of prisons needed to be reduced and, by doing so, only one warden was used for many inmates, thus optimising control (Enzensberger 2019). The warden controlled all individuals in the prison from a central location, where the inmates therefore did not know 'who and what he was watching'. Bentham (1791) devised a dimension in which individuals lived in a precarious and insecure condition without ever knowing when to act. This led the users (inmates) of the Panopticon not to misbehave, but to behave ethically. Bentham's project was essentially applied all over the world (Fagan 2019). Nevertheless, the idea was in many cases strongly misunderstood because Bentham's purpose was completely different from the prison and oppressive use that was attributed to it over time (La Monica 2014). But why recall Bentham, his engineering, his theory on prisoner surveillance, today, in the year 2022? How is it possible that a theory from 1791 can find application in modern society and be useful in the new era of digital information and prisoner control? The Panopticon is often compared to the modern era with regard to technological innovations that collect and disseminate data on the lives of ordinary people (Cesaris 2001). In the modern context, these instruments are perceived as dangerous and have an overall negative view. Governments and companies, thanks to the analysis of big data, are able to get hold of a great deal of information on each individual, without his or her knowledge. A world very similar to that of the panoptic, where at the centre of the building the 'watchman' controlled and, through control, modified the behaviour of the prisoners (Samek 2004). In order to connect definitively to the vision of the Panopticon in the modern era it is necessary to recall a second phase of Bentham's idea (1791) and that is when he decided to build the anti-Panopticon. Bentham, in fact, realised that his idea had been misunderstood: the object created had been transformed into a means of continually oppressing the individual and limiting his freedoms; a totally different vision from his initial project, aimed at the re-education and moralisation of the prisoner. In fact, Bentham's objective was not to prevent the individual from expressing his personality and ideologies, but, on the contrary, to make the individual express himself through ethical and just behaviour in order to create an advantage for society (Rudan 2013). Bentham (1791) did not conceive the Panopticon as a model purely related to prisons, but as a prototype that could be applied to all social environments. Those living within the Panopticon did not have to undergo surveillance and lead their existence in an inactive and passive world, but had to change their attitudes in order to make them transparent and morally correct (i.e. without the warden being able to accuse them in relation to their actions). Transparency and ethics, not oppression and surveillance: the ideas behind them 
were very different from those commonly associated with a prison (Pellegrino 2011). The control of Big Data, today, comes closer to the ideal of the English philosopher and assumes the role of a new "watchman" who, unlike the historical application, must aim at an improvement of society and the conditions of citizens, not at a repression of the ideologies of the individual (Perri 2020). Law no. 4 of 19 January 2001 introduced into the Italian judicial system the possibility of ordering "electronic monitoring" for persons under arrest or home detention in order to avoid police checks (pursuant to Article 275 bis of the Code of Criminal Procedure and Article 47-ter, paragraph 4, of Law 354/1975). The provision provides that the "consent of the person concerned" must be acquired and that there must be actual availability of the electronic monitoring devices by the police authority. Law no. 136 of 5 June 2012 provided that upon entering the prison, the suspect or defendant must give consent to the possible use of electronic bracelets and that this consent must be immediately communicated to the competent judge. Law no. 119 of 15 October 2013 on combating gender-based violence (D'aiuto 2021) (gender-based persecutory acts and other related offences), extended the possibilities for the application of the use of electronic bracelets to cases of application of the precautionary measure of removal from the family home, provided for in Article 282-bis of the Code of Criminal Procedure. The use of electronic means of control is also provided for by Law no. 67 of 28 April 2014, "Delegation to the Government on the subject of non-custodial detention sentences", which, in art. The use of electronic means of control is also provided for by Law no. 67 of 28 April 2014, "Delegation of the Government on the subject of non-custodial detention sentences", which, in Article 1, letters b) and c), provides for the mandatory use of home detention for offences punishable by arrest or imprisonment of no more than three years, and the optional use of home detention for offences punishable by imprisonment of between three and five years; letter d) adds that, in the cases indicated in letters b) and c), the judge may prescribe the use of the special methods of control provided for in Article 275-bis of the Code of Criminal Procedure. For many years, electronic personal monitoring devices were hardly used and there was much controversy about their use and cost. Since 2013, in Italy, some Judges for Preliminary Investigations (G.I.P.) have started to use the "electronic bracelet" for the measure of house arrest and for home detention with remote control. As a result of the increased attention paid to this issue, about a hundred devices have been used. Decree-Law no. 146 of 23 December 2013 amended Article 275-bis of the Code of Criminal Procedure, providing that the judge, when ordering the measure of house arrest, must prescribe remote control procedures "unless he considers them unnecessary": as a result of the rule, the devices currently in use are the total of those available. The same decree has modified the regime of the control modalities in the execution of the alternative measure of home detention by introducing art. 58-quinquies to the Law 354/75, by effect of which the Surveillance Magistrate and the Surveillance Court in ordering the home detention (also "during the execution of the measure") can "prescribe control procedures also through electronic means or other technical instruments" (Di Stefano 2021). On 31 May 2013, the Parliamentary Assembly of the Council of Europe, in order to promote alternatives to detention, adopted Resolution 1938 (2013), according to which sanctions applied in the "external" penal area (home detention) represent the first address by the
Judge. On 19 February 2014, the Committee of Ministers of the Member States of the Council of Europe adopted Recommendation CM/REC (2014) 4 highlighting that "the electronic monitoring system" can help reduce the use of deprivation of liberty while ensuring effective monitoring in the community, but, recommending, that it should in no way replace the building of a constructive relationship with the offender by the staff competent to deal with him in the community (Bassi \& Von Borries 2016). In essence, the tool is used in the context of the execution of so-called 'community measures' and the Council of Europe recommends that it be combined with other interventions and support measures aimed at social reintegration, in order to ensure control during execution and to inhibit recidivism (the return to committing criminal acts) in the long term. The purpose of the Recommendation is to define the ethical principles in accordance with which national authorities may adopt electronic surveillance, stating that "particular care must be taken, when using electronic surveillance, not to compromise or replace the building of constructive professional relationships with defendants and offenders by the staff responsible for taking them into custody in the external criminal justice area". It should be emphasised that the imposition of technological control can be a useful addition to the existing social and psychological arrangements for taking charge of any defendant or offender. Finally, the Recommendation lays down minimum standards to ensure effective supervision that respects human rights. In this sense, the basic principles are laid down, including the following: a) the need for an organic, clear and transparent discipline regarding the types, duration and methods of execution of electronic monitoring measures; b) the necessary judicial nature of the decision ordering the measure, or at least the provision of judicial remedies against such a decision; c) the prohibition of discrimination; d) the proportionality of the measure; e) the limitation of invasiveness to the minimum necessary; f) the transparency and publicity of the procedures in case of involvement of the private sector; g) the protection of the right to confidentiality, with particular reference to the data collected and processed during enforcement (Grassia, 2015).

\section{THE FIRST CONCEPT OF CONTINUOUS SURVEILLANCE: BENTHAM'S PANOPTICON AND FOUCAULT'S CONTRIBUTION}

The Panopticon is an architectural figure conceived as an institutional building of control. It was designed by the philosopher Jeremy Bentham towards the end of the 18th century (Baculo 1996). The principle behind this structure was the dissociation of the 'seeing and being seen' pair. The Panopticon presented itself as a ring-shaped construction with a tower in the centre with large windows opening towards the inner part of the ring (Hans 1952). The building was divided into cells with two windows, one facing the central tower and the other the outside, so that light could pass through the cells and make the inmates clearly visible. In this way it was possible for a large number of prisoners to be watched by a single guard, located in the central tower. The prisoners were constantly watched but had no way of observing, as they were separated from their cellmates by thick walls. This allowed order to be maintained within the facility; individuals were separated into individual units that were easily 
controlled. The main effect of the Panopticon was to induce in the prisoner a conscious state of visibility so that the dynamics of power could be expressed (Bentham 1791). He analysed in depth the dynamics within the Panopticon; he studied the role of each actor, from the director of the facility to the inmates. Bentham (1791) commissioned the architect Willey Reveley to give the Panopticon an architectural structure. The aim was to exert a form of constant control, to induce the inmates to follow the rules. With the advance of industrialisation in England and the increase in the number of factories and workers, Bentham (1791) suggested that his model could be applied not only to prisons but also to industries, kindergartens and schools. Bentham's proposal aroused great interest in the British government (Harrison 1983). Bentham saw his model of constant control of the prisoner as: a) the appropriate means of creating the 'uneasy consciousness' of being observed; b) the consequence of the prisoner's subjection to the rules; c) a valid and effective means of deterrence for those being controlled. One of the advantages and objectives of the Benthamian model was to induce the subject to respect the rules in force in the context in which he found himself, by virtue of the cardinal principle according to which power had to be "invisible and unverifiable", which was the presupposition and condition for the functioning of the apparatus imagined in this model. All this, in its prison structure, implied the futility of the presence of bars, heavy locks, and so on (Foucault, 1976). According to Bentham (1791), the architecture of the building and the clear separation of spaces, which he described in his work, were sufficient to make the prison safe. Bentham was a philosopher of law belonging to the philosophical current of utilitarianism who designed the "Panopticon" in a historical period in which the problem of the efficiency of justice and the question of prisons were highly felt, because they had to respond to the ever-increasing need for "order" within a society that ill tolerated vagrants, beggars and more generally the unproductive, in the face of a dizzying increase in delinquency (Engelmann 2003). The prisons of the time were overcrowded, the inmates had inhumane hygienic conditions and yet the prisons did not guarantee security, given the high rate of escapes. In this context, a lively debate developed about the function of the prison and possible remedies to a solution that involved the sanitary area and very high economic costs. Bentham's idea (1791) was very successful because it revolved around a different conception of the prison and the prison system: the idea of control of the body and physicality penetrated the psyche of the subject and resulted in a continuous and effective control of space and time (Bowring 2021). It was the very architecture of the prison that acted directly on individuals (Weinreich 2021). A comparison could be made (with all the possible limitations) between the idea of the Benthamian prison and the modern systems of electronic control, which concern the deprivation of time and space, the control on the movements of the subject and therefore the transposition of the prison from the closed place, as we imagine, to the free one: an extension outside the prison walls of the control, which from visual becomes virtual, allowing to know where the subject is and if he respects or not the prescriptions that have been imposed (Brooks 2002). The monitor is, as Bentham also imagined, invisible, while the effects of surveillance are visible, as evidenced by the sign of punishment (today, the electronic bracelet). The fact of wearing this instrument also constitutes, in modern reality, a deterrent for those under surveillance and reminds them of the seriousness of the restrictive measure to which they are subjected (Cox 2009). In some ways, the stigmatisation may be even greater than imprisonment, for example in cases where the subject is allowed to move outside the perimeter of the home to go to work, where he or she may be exposed to the disapproval of colleagues (Ferraro 2010). The advantages of applying the modern idea of 'electronic surveillance' are not so dissimilar to those envisaged in the Panopticon: the latter, in fact, allows for more intense and continuous control than the sporadic one that usually occurs in penal institutions or through social workers. At the same time, electronic surveillance is a remedy for prison overcrowding, allowing a large number of people to be released from prison. Modern electronic surveillance (SE) shares with prison the effect that Foucault recognises in Bentham's Panopticon: "to induce in the prisoner a conscious state of visibility that ensures the functioning of power. To make surveillance permanent in its effects, even if it is discontinuous in its action" (Foucault 1976). The Panopticon "is in fact a figure of political technology that can and should be detached from any specific use", therefore, this model, brought back to its ideal form, can include all the modes of control, including the use of electronic surveillance devices, which go alongside the traditional forms of imprisonment in prison. The punishment therefore moves from a place specifically created to perform this function to the home of the offender. The electronic bracelet adds to the alternative measures to prison the certainty of control: every violation, even the smallest, is detected. Bentham's model imagined the prison as a circular building in the centre of which he placed a single man, called an 'inspector', who controlled people's movements through a skilful play of light and shadow, all based on a form of visual control: 'seeing without being seen' (Foucault 1976). Foucault, in his most famous work "Surveillance and Punishment", also focuses on the historical analysis of punitive, sanctioning and penitentiary systems, including Panopticism, a form of power exercised through the meticulous control of spaces. In his work, Foucault (1976) defines the Panopticon and naturally analyses its functions. According to the author, the main effect of the Panopticon was to induce in the prisoner "a conscious state of visibility that ensured the automatic functioning of power". Surveillance had to be constant in its effects, even if discontinuous in its action. Bentham (1791), as is well known, structured the Panopticon in such a way that the power was "visible and unverifiable": "visible" because each prisoner constantly had the high tower in front of him from which he was observed; "unverifiable" because he was never certain that anyone in that tower was watching him, since one of the strategies Bentham (1791) planned was that the prisoner could never see the actual presence of the guard or his shadow. To this end, shutters were designed inside the central surveillance room, and there were no doors to pass from one sector to another, but chicanes. Foucault's (1976) analysis of power still has an important influence on contemporary sociology. His study focuses on technologies and the orthopaedias of the soul: power is not defined by its capacity for repression but through social practices such as technology and bureaucracy, ways of organising internalised forms of control. According to Foucault (1976), power transits through the subject and its biological essence. Power in fact has to be analysed in its details and in the apparently hidden forms of discipline and surveillance, thus from a microphysics of power, which analyses 
the power that insinuates itself into the management of bodies. The management of the body is linked to its economic use, the body is invested by relations of power and domination and its construction as a workforce is only possible if it becomes part of a system of subjugation. The body, according to Foucault, becomes a useful force only when it is both a productive body and a subjugated body (Foucault 1976). This is precisely a microphysics of the power that institutions bring into play, which assumes that the power that is exercised is conceived as a strategy and not an appropriation, just as within the Panopticon. Lyons (1997) does not claim that contemporary society totally reflects Bentham's (1791) model of the Panop theticon. In the text "The Electronic Eye", he uses the term Synopticon to define the condition of contemporary society, denying that it can be Panopticon; he now uses the term Comopticon, which rehabilitates the existence of Bentham's model (1791) in the contemporary world, integrating it with that of the Synopticon: "We are faced neither with the old Panopticon described by the English philosopher and engineer Jeremy Bentham, nor with a superfetation of it. In the case of the model proposed by Bentham, we were faced with a power exercised by an obscure observer power. In the Panopticon, therefore, the few observe the many. We are faced with a situation in which the many scrutinise and control the few. A change in the forms of control that has profound repercussions on the social fabric.

\section{THE ARCHITECTURE OF THE PANOPTICON AND THE MODEL AND RE-EDUCATIONAL MODEL ENVISIONED BY BENTHAM}

The building, from an engineering point of view, had a circular shape and was made up of two concentric rings: the innermost one housed the inspector's house, the fulcrum of the whole system; while the outermost one was occupied by the prisoners' cells, narrow and long and with a glass at one end and an iron grating at the other, so that the prisoner could always be in the light and therefore observed (Zanuso 1989). Between the centre and the circumference was the intermediate or annular area. Bentham (1791) also assigned precise dimensions to the cells as well as to the facility. The whole circumference would have been one hundred feet $(30.48 \mathrm{~m})$ in diameter and there would have been forty-eight cells on each floor, six to eight feet wide and thirteen feet deep. The walls were to be two feet thick. Bentham (1791) then continues the detailed description by giving the diameter of the inspector's residence (feet $35=\mathrm{m} .10 .30$ ), the dimensions of the intermediate area and all the heights, both of the individual cells and of the residence and the whole building (Ignatieff 1982). The Panopticon became the architectural translation of the image of the human being that dominated European culture in the late nineteenth and early twentieth centuries, described in "Machine Man" by Offrey de La Mettrie (2015). The Panoptic was a "device rather than a building". Its mechanism and architecture were an instrument whose technology was used as a means for the formation of a new morality of the individual to be achieved through work. Hanway (1775) particularly influenced Bentham (1791) on this subject and many of his theories were found in the Panopticon. Bentham (1791) openly described the Panopticon as 'a way of obtaining the power of the mind over another mind'. The shape of the building defined well the power structure within it: the governor was housed in the cylindrical pavilion and looked out over the space in between, illuminated by the light that filtered through the large windows of the cells, from which the prisoners could never see the darkness of the central building. The prisoner was destined to be subjected to constant and continuous virtual control, as he could never know when the guard was spying on him. To make this surveillance possible at night as well, Bentham (1791) placed small lamps around the outer rotunda so that the cell entrances were always illuminated. The serious defect of this monobloc, however, was the rigidity of its structure and its lack of versatility in adapting to the changing prison situation and the continual evolution of the concept of punishment. It was Bentham's indications (1791), rather than his utopia, that found wide application at the beginning of the 19th century because they made it possible to use a reduced number of guards in prison structures without affecting their security. Jeremy and Samuel Bentham, in their Panopticon, a prototype of moral architecture or a place for the construction or redefinition of virtue itself, sought to combine the isolation of prisoners with industrial production (Melossi \& Pavarini 1977). The original vocation of the project was that of a factory, which, thanks to its centripetal organisation, could make all the workers constantly visible to the governor/supervisor, located in the central lantern, so that the continuous control combined with the work would influence the consciences of the prisoners, bringing about a moral change. As in the houses of correction, the prisoners, according to Bentham (1791), were to be divided according to their working capacity and not according to their offences against the law (Pellegrino 2010). Among the aims of this structure, the productive one had a certain importance: through work, the prisoner would not be a dead weight for the State but would have provided for his maintenance and amortised his management costs (Bentham, 1791). Work had, for the creator of the Panopticon, an educational function, he believed, close to the philanthropic attitude that pursued the rehabilitation of man through rational methods, that men should be rehabilitated because they were part of a production mechanism (Postema 1998). Forming new men through work: this was the disturbing privilege that could be experienced by adopting this device, applying the logic of inspection, a guarantee of the implementation of this mechanism. The logic of inspection was architecturally the organising principle of the model, which transformed the prison from an inert space into a disciplinary device. Total vision is at the heart of panoptic architecture and the prison is the place of its representation. Bentham (1791) structures his layout based on the rules of vision as he needs clarity to observe the scene in which the prisoners are perfectly visible and controllable (Siltala 1990). He starts from an archetypal figure that alludes to perfection and unity and, using a radial arrangement based on optical rays, he arranges a series of peripheral points, each corresponding to a single cell; circular vision for those in the centre of the composition but denied vision for those on the opposite side; in the cell, the prisoner can only be subjected to an inquiring gaze, "a gaze that creates uncertainty and procures surrender" (Bentham 1791). Bentham's idea (1791) is "marvellous and frightening": marvellous because it is a brilliant synthesis of ideas, impulses, ferments, ideologies, science and everything else that went through this revolutionary epoch, but at the same time frightening because it is the delusional stratagem of a man who wanted to reshape the lives of "deviant" men (Poggi 2006). On one thing historians agree: the Panopticon was an unconventional 
piece of single engineering. Every page of its description contains some architectural innovation, or some technical refinement. "One person can supervise hundreds", this was the informative principle of this device of which Bentham (1791) gives detailed indications of the architectural elements required for construction. The building was entirely made of brick while the vaults of the cells and corridors were made of stone, the doors were made of wood but covered with iron and, with the intention of creating an acoustic system analogous to the visual one, the tower and the cells were connected by tin tubes used by the warden to speak to all the inmates at the same time: 11 tubes which, in the schemes following the original, were replaced by megaphones from which orders could be given. Together with undoubtedly improbable objects, such as the governor's lantern and doors that work with wire, there were also numerous innovative proposals, especially from a technological point of view: the use of iron and glass, together with the design of an integral heating and ventilation system, were particular technical refinements, never used in previous prison projects. Bentham (1791) was enchanted by the properties of glass, which did, however, lead to problems of heat dissipation, especially in the outer walls, which is why the stone vaults of the cells were retained in Revely's 1791 design. Bentham and Reveley (the latter's brother) then designed a double circle of iron columns inside the rotunda on which rested a glazed roof and inspection galleries. The use of iron for fixed structural supports in a building of such proportions was innovative, to say the least, and greatly improved the function of the inspection, which would have been greatly impaired by the use of a brick structure. The sections of these pillars were hollow, so they could be used to pass warm air and so, without changing the structure of the building, Bentham (1791) created a thermal ventilation apparatus by integrating the ventilation and heating systems. Fresh air could be extracted from a Franklin stove, placed under the centre of the rotunda and, once heated, the air would be distributed inside the cells by means of a radial apparatus of pipes, placed vertically in the centre of each cell, so as to reduce the risk of them being used surreptitiously by prisoners for conversation (Fig.1). The building was also fireproof, within the limits of the technology of the time. Iron was also used for the cell gates, circular galleries, staircases, balustrades and the four bridges connecting the loggias to the central part, which were built later. Bentham (1791) included a rudimentary bath, consisting of an iron seat, the waste from which went into a closed sewer. For washing and drinking there was a continuous supply of cold water collected in an annular cistern located under the roof, from which the water was extracted by means of a hand pump. To make good use of the limited space allotted to each prisoner, the beds were folding or could be raised to the ceiling with pulleys so that there was room for frames during the day. What is perhaps surprising, considering the wide influence of the inspection principle, is that the Panoptic model was only used from a configurational point of view, while the technological innovations were not widely successful. Prisons built in Britain include Gandy's Lancaster Castle Gaol, to whose initial centripetal arrangement, to which the inspection principle had been applied, acoustic surveillance was added only later, through openings in the ceilings and small holes.

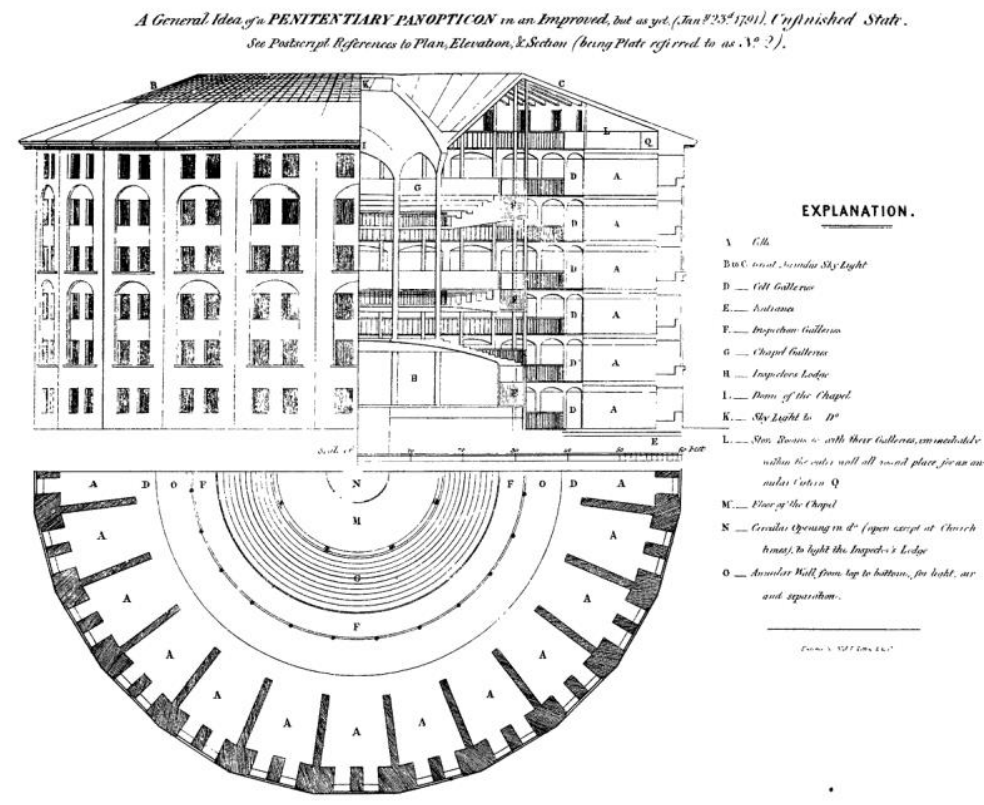

Fig. 1 The Panopticon project 


\section{THE POST-PANOPTICON: MODERN ELECTRONIC SURVEILLANCE DEVICES AND THEIR CHARACTERISTICS}

If Bentham's Panopticon helped to identify innovative forms of prisoner control in the past, modern technological evolution is certainly promoting the use of new effective tools of "electronic surveillance" of prisoners (Pajardi 2009). Over time, there has been a shift from verifying the presence of an individual in a given place to continuous surveillance of their movements, thanks to new satellite technologies (Zuboff 2019). The new 'electronic surveillance', of its kind, does not guarantee protection, but only allows to know in which place or space a subject is. The system needs to be implemented by a constant and organised management of the surveillance service, able to intervene 24 hours a day, (thus continuously) in case the person under electronic surveillance should violate the imposed prescriptions for various reasons. Electronic surveillance is essentially linked to the so-called "electronic bracelet": the introduction of this control instrument guarantees a level of surveillance comparable to the permanence of the prison (Ciarpi 2008). The electronic instrument is applied to the ankle of the subject receiving the measure, just like a bracelet and connected to a network by a control unit located in the home of the same, defined as "local surveillance unit" (Gianfrotta 2013). This device receives the signals transmitted by the electronic bracelet within a well-defined perimeter. In the event that the detainee strays from the defined boundary, or tries to damage one or both devices, the local surveillance unit will send an alarm signal that will immediately activate police controls. Basically, "the electronic bracelet" is intended to signal the undue removal of a person subject to this measure from the defined perimeter, of the house. Since the electronic communication between the bracelet and the receiver takes place exclusively in the area within which the person under surveillance is obliged to stay, the individual is only controlled when he is in this defined area and his possible movements outside (in the case of escapes) are not known. The system, therefore, could not control the escaped person outside the defined perimeter. The diligent wearing of the bracelet implies direct responsibility on the part of the person: all information or anomalies are encoded and sent to an operations centre via the fixed or mobile telephone signal, including attempts at malicious tampering or any technical problems not attributable to the person receiving the measure. The transmitter (electronic bracelet) consists of a wristband which, once installed, is able to instantly transmit any type of tampering, as it automatically generates an alarm. The transmitter is made of fireproof material and is watertight, allowing the subject to be able to stay in the water, indoors; it is made of hypoallergenic material and the weight and size are contained (Hucklesby \& Holdsworth 2020). No person can interfere in the communication between the transmitter and the receiver; the latter is powered by the home's electricity supply, and is equipped with a back-up battery that is activated to support the device in the event of power outages. This modern system is able to carry out self-diagnosis to detect faults or attempts at tampering. On the basis of a complex and delicate computer system, each control centre monitors the devices installed in its area, operating 24 hours a day, all year round, without interruption. Alarms sent by the receiver are immediately received and analysed to provide an appropriate response. Today, data dissemination between the fixed device and the operations centre is ensured by a control and monitoring system using the widespread mobile phone system. The 'electronic surveillance' provisions provide for random checks at the address of the installed system, although its operation or presence can be verified from outside the home, using state-of-the-art electronic tools, as well as surprise checks to ascertain that the recipient of the measure is actually present in the home (Lévy et al. 2019). Given the proliferation of crimes falling under the provisions of Article 612-bis of the Italian Criminal Code (Persecution), the technology described above can be used to protect 'one subject against another', with the aim, for example, of preventing the guard from approaching the home of the subject who is being 'persecuted' (in the case, for example, of Stalking). The scientific literature calls this new function 'bilateral electronic surveillance': essentially, the receiver is placed at the home of the person to be protected and sends an alarm signal when the person under surveillance approaches beyond a set distance. Taking into account the evolution in the field of mobile telephony and data transmission, it is now possible to protect a person even outside the walls of his home, by means of a mobile receiver that he will wear and that will send an alarm signal to the central unit if the person under surveillance gets too close (Laurie \& Maglione 2020). This is enabled by the GPS (Global Positioning Satellites) system, which makes it possible to monitor a subject even outdoors (it is a system similar to the one that is placed in cars). According to the type of prescriptions imposed on the monitored person (such as being able to leave home to go to work, etc.), the GPS technology is able to report the spatial position of the monitored person, the route to work, the actual presence of the person at work and the entire reverse process for returning home at the prescribed hours. Recent and further electronic surveillance technologies use the "voice verification" system, i.e. the use of individual voiceprints: this system allows to establish whether the person is actually in that place at a specific time (Nellis 2021). In the same way that a personal fingerprint is used to unlock the functions of a mobile phone, a biometric voiceprint is released by the person at the time of registration and recognised by the system. For the purposes of control, the person under surveillance will have to repeat a series of phrases assigned by the system in his or her own voice. This will allow the identity of the person to be checked by means of the voiceprint and the location, the latter confirmed by the recognition of the telephone number. Any violations will result in appropriate judicial action being taken. Voice verification is, therefore, an intelligent system that proves a person's presence and can be used for other alternative measures to prison or community or in the case of permits or other benefits granted to prisoners (Jahangir et al. 2021)

\section{ELECTRONIC SURVEILLANCE: FROM THE CONSENT OF THE DETAINEE TO THE PROTECTION OF RELATED HUMAN RIGHTS}

As already anticipated, Law No. 4 of 19 January 2001 introduced into the Italian judicial system the possibility of having "electronic surveillance" for persons under arrest or home detention, in order to avoid police checks (pursuant to Article 275bis of the Italian Code of Criminal Procedure and Article 47-ter, paragraph 4, of Law 354/1975). However, the provision requires the "consent of the person concerned" and the actual availability 
of the devices by the police authority. Article 275-bis of the Italian Code of Criminal Procedure expressly refers to the necessary requirement of the "consent of the person concerned" for the application of the electronic bracelet and regulates the modalities with which such manifestation of will must be made, providing, in the second paragraph, that "the acceptance or denial of the consent" must take place "with an express declaration made to the officer or agent in charge of executing the order that has ordered the measure" and that this last one transmits such declaration "to the Judge who issued the order and to the Public Prosecutor, together with the report provided for by Art. 293, paragraph 1" of the Italian Code of Criminal Procedure (Marandola 2015). Moreover, the Article 275-bis in question also provides that, in case of "lack of consent", the judge will provide for the measure of pre-trial detention in prison. First of all, a doubt arises on the so-called "voluntariness" of the consent, given that the noncompliance with the electronic control produces the application of a much more afflictive precautionary measure (imprisonment). The option chosen by the legislator seems to be correct, since a different solution would imply the use of means used without the knowledge of the person to be monitored, which, besides being a hypothesis hardly feasible in practice, also seems scarcely compatible with the need that the person subject to the precautionary measure is not exposed to inhuman or degrading treatment, or would make the experimentation of the electronic bracelet only symbolic (Diddi \& Geraci 2015). Finally, as regards the hypothesis of 'dissent', it seems that, in addition to the formal declaration, a declaration by concluding facts is also envisaged. Paragraph 3 of Article 275-bis of the Italian Code of Criminal Procedure provides that the subject who has accepted the application of means or instruments suitable to ensure remote control "is obliged to facilitate the installation procedures and to observe the other prescriptions imposed on him". From this it can be deduced that the breaches recorded in this respect can only represent an implicit revocation of the 'electronic surveillance' consent previously given. The advantages and objectives of the latter, which seemed to be easy to achieve, were initially the subject of lively criticism on several levels (Cassibba 2016). First of all, the excessive interference in the private sphere of the person subjected to these particular methods of control is disapproved of, and the unequal treatment that would occur between those who have a fixed home, a telephone and have the possibility of paying the costs related to the electronic control, compared to those who do not have all that (Jones 2014), is also criticised. Furthermore, the increase in criminal control is criticised, which, despite decriminalisation policies, leads to an increase in the prison population (which generates overcrowding in prisons), resulting in the search for alternative solutions to prison. The new form of electronic control would also appear to be open to criticism in other respects, which concern the primary rights recognised to every citizen by Article 2 of the Italian Constitution, including "that of one's own dignity, honour, respectability, confidentiality, intimacy and reputation" (Carcano \& Manzione 2001).

\section{CONCLUSION}

Time has shown that the needs for prisoner control, personal re-education processes, emotional literacy, moralisation, resocialisation, work and social defence against crime, although they have concerned different eras, as have been different approaches, social theorisations, engineering innovations, as in the case of Bentham, still today, are the subject of debate and experimentation. The forms of social coexistence have always envisaged ways of repressing/containing deviant behaviour deemed unacceptable by society, contrary to the expectations of its members and the maintenance of social order. Deviant behaviour identified and sanctioned by criminal law constitutes criminal offences. As a social 'construction', the meaning of punishment cannot be explained exclusively in functional terms: it depends on the historical period and the cultural conditioning of the social organisation in which it is embedded. From the Panopticon of 1791, we have moved on to forms of control of the person that exploit the most innovative technologies. Today, electronic or satellite monitoring is considered an efficient system of home detention, aimed at controlling and modifying the behaviour of the offender with the aim of improving it. This measure represents an alternative sanction to imprisonment and allows offenders, who would otherwise be in prison, to remain in their own homes, with restrictions on their freedom. The use of electronic monitoring is also a form of crime control that is closely linked to social control, aimed at achieving behaviour that complies with criminal rules and the rules of society, with the use of strategies and sanctions designed for this purpose. The condemnation of deviant behaviour through the imposition of a penalty limiting freedom of movement has a variety of objectives, but its instrumental function is to reduce or contain crime rates. In this sense, punishment becomes simply an instrument of crime control. Sentences involving the use of electronic monitoring were initially developed in the United States, but this system for offenders is in force today in many parts of the world. In this general climate, "electronic surveillance" has often been used, in Italy, not as an effective alternative solution to detention, but as a mode of enforcement of alternative measures to detention, ending up representing an additional restriction to already compressed spaces of freedom. If used as an executive modality, the role of social workers could also change, as they would end up becoming remote controllers of the good functioning of the control apparatus, instead of establishing a direct relationship with the person under surveillance, aimed at his/her reintegration in the social context. This would have the further consequence of favouring the neutralisation of dangerousness, i.e. the security profile, to the detriment of re-socialisation, which should instead characterise alternative measures to detention.

\section{ACKNOWLEDGEMENTS}

I would like to thank the research group in "deviance and criminality" at the University of Enna "Kore" for their important contribution during the selection of the bibliography for this work.

\section{REFERENCES}

[1] Baculo A. Il Panopticon di Bentham e 1'architettura della visione totale. In Bérénice anno IV, (12). Frosinone (Italy) 1996.

[2] Bassi A, Von Borries C. Il braccialetto elettronico fra luci ed ombre Cassazione Penale 2016; 9: 3127-3139.

[3] Bowring J. The works of Jeremy Bentham- Volume 1. Milano (Italy): New Publisher 2021. 
[4] Brooks T. Utilitarianism, Capital Punishment and Innocent Persons. A Defence of Bentham. Review Journal of Philosophy and Social Science 2002; 27: $17-32$

[5] Carcano D, Manzione D. Custodia cautelare e braccialetto elettronico. Milano (Italy): Giuffrè 2001.

[6] Cassibba F. L'indisponibilità del "braccialetto elettronico": le Sezioni Unite escludono automatismi decisori ma residuano dubbi. Processo penale e giustizia 2016; 5: 175-182.

[7] Cesaris L. Dal panopticon alla sorveglianza elettronica. In: Bargis M. (a cura di). Il decreto "antiscarcerazioni”. Torino: Giappichelli 2001: 49-79.

[8] Ciarpi M. Il monitoraggio elettronico e satellitare delle persone sottoposte a misure alternative alla detenzione o di comunità: l'esperienza scozzese. Rassegna penitenziaria e criminologica 2008; 2: 19-49.

[9] Cox B.E. Bentham on Guardianship: A Special Relation for Protection and Representation. Journal of Bentham Studies 2009; 11

[10] D’Aiuto G. Stalking. Aspetti sostanziali, processuali e profili psicologici. Milano (Italy): Giuffrè Francis Lefebvre 2021.

[11] Diddi A., Geraci R.M. Misure cautelari 'ad personam' in un triennio di riforme. Torino (italy): Gisppichelli 2015

[12] Di Stefano P. Codice di procedura penale. Annotato con la giurisprudenza. Con appendice di aggiornamento novembre 2021. Napoli (Italy): Edizioni Giuridiche Simone 2021.

[13] Engelmann S. Indirect Legislation: Bentham's liberal Government. Polity 2003; 35 (3): 369-388.

[14] Enzensberger H.M. Panopticon. Torino (Italy): Einaudi 2019.

[15] Fagan J. Panopticon. Milano (Italy): Carbonio Editore 2019.

[16] Ferraro F. Direct and Indirect Utilitarianism in Bentham's Theory of Adjudication. Journal of Bentham Studies 2010; 12: 1-24.

[17] Foucault M. Surveiller et punir. Naissance de la prison, (1975), (trad. it. Sorvegliare e punire. Nascita della prigione). Torino: Einaudi 1976.

[18] Gianfrotta F. Il braccialetto elettronico questo sconosciuto. Rassegna penitenziaria e Criminologica 2008; 2: 63-77.

[19] Grassia R. G. Il braccialetto elettronico: uno strumento inespresso. Quando la tecnologia è al servizio dell'uomo, ma la copertura finanziaria non è al servizio della tecnologia. Archivio penale (web) $2015 ; 3$.

[20] Hans W.N. Bentham and the Utilitarians. In: Pioneers of English Education. London: Judges, 1952.

[21] Hanway J. Defects of Police, s. e., London 1775.

[22] Harrison R. Bentham. London: Routledge \& Kegan Paul 1983.

[23] Hucklesby A, Holdsworth E. Electronic monitoring in probation practice. HM Inspectorate of Probation Academic Insights 2020; 08.

[24] Ignatieff M. A Just Measure of Pain. The Penitentiary in the Industrial Revolution 1750-1850 (trad. it. Le origini del penitenziario. Sistema carcerario e rivoluzione industriale inglese 1750-1850). Milano (Italy): Mondadori 1982.

[25] Jahangir R, Wah The Y, Friday Nweke H, Mujtaba G, Ali Al-Garadi M, Ali I. Speaker identification through artificial intelligence techniques: A comprehensive review and research challenges. Expert Systems with Applications 2021; 171. https://doi.org/10.1016/j.eswa.2021.114591.

[26] Jones R. The electronic monitoring of offenders: Penal moderation or penal excess? Crime, Law and Social Change 2014; 62 (4): 475-488. https://doi.org/10.1007/s10611-014-9537-3

[27] La Monica M. Dal Panopticon di Bentham a modelli parzialmente panottici. Prigioni tra Settecento ed Ottocento. Milano (Italy): Pitti Edizioni 2014.
[28] Laurie E, Maglione G. The Electronic Monitoring of Offenders in Context: From Policy to Political Logics. Critical Criminology 2020; 28: 685-702. https://doi.org/10.1007/s10612-019-09471-7

[29] Lévy R, et al. Le bracelet électronique: action publique, pénalité et connectivité. Médecine \& Hygiène 2019.

[30] Lyons G. Jeremy Bentham's Ethics of Surveillance: a Critical Analysis. Journal of Thought 1997; 43-52.

[31] Marandola A. Carcere, arresti domiciliari e braccialetto elettronico. Periodico: Giurisprudenza italiana 2015; 167 (7 9: 1723-1725.

[32] Melossi D, Pavarini M. Carcere e fabbrica. Alle origini del sistema penitenziario XVI-XIX secolo. Bologna (Italy): il Mulino 1977.

[33] Nellis M. Electronic Monitoring Around the World. Criminology and Criminal Justice 2021; Oxford University Press.

[34] Offray de La Mettrie J. L'uomo macchina (a cura di Polidori F.) Minesis Filosofia/scienza 2015.

[35] Pajardi D. Oltre a Sorvegliare e punire. Milano: Giuffrè 2009.

[36] Pellegrino G. La fabbrica della felicità. Liberalismo, etica e psicologia in Jeremy Bentham. Napoli (Italy) Liguori Editore 2010.

[37] Perri P. Sorveglianza elettronica, diritti fondamentali ed evoluzione tecnologica, Milano (Italy): Giuffrè 2020.

[38] Poggi F. Cosa esiste? Un'introduzione all'ontologia di Bentham. Materiali per una storia della cultura giuridica 2006; 36 (1): 39-53.

[39] Postema G.J. Bentham's Equality-Sensitive Utilitarianism. Utilitas 1998; 10 (2).

[40] Raccomandazione CM/REC (2014) 4. Comitato dei Ministri - Stati Membri del Consiglio d'Europa.

[41] Rudan P. L'inventore della Costituzione. Jeremy Bentham e il governo della società. Bologna (Italy): Il Mulino 2013.

[42] Samek L.G. L'utilità del bene. Jeremy Bentham, l'utilitarismo e il consequenzialismo. Milano (Italy): Vita e pensiero 2004.

[43] Siltala R. Punishment and Discipline in the Age of Reason. Enlightenment Philosophy, Especially in Light of Jeremy Bentham's Panopticon. In: Campbel T.D. (ed), Law and Enlightenment in Britain. Aberdeen University Press 1990

[44] Weinreich SJ. Panopticon, Inc.: Jeremy Bentham, contract management, and (neo)liberal penality. Punishment \& Society. 2021;23(4):497-514. doi: $10.1177 / 14624745211023457$

[45] Zanuso F. Utopia e utilità sul pensiero filosofico-giuridico di Jeremy Bentham. Milano (Italy) Cedam 1989.

[46] Zuboff S. Il capitalismo della sorveglianza. Milano (Italy): Luiss University Press 2019.

\section{AUTHORS}

First Author - Nicola Malizia, Associate Professor of Sociology of Law, Deviance and Social Change, Faculty of Sciences of Man and Society, University of Enna "Kore" - Italy.

Italy: telephone +393346386572 .

Correspondence to: nicola.malizia@unikore.it 